\title{
MANAGEMENT OF AGE-DIVERSE EMPLOYEES IN AN ORGANIZATION WITH HIERARCHICAL CULTURE ON THE EXAMPLE OF AQUANET S.A.
}

\author{
Joanna RATAJCZAK \\ Poznań University of Economics and Business; joanna.ratajczak@vp.pl, ORCID: 0000-0002-0634-7545
}

Purpose: Identifying the dependence between the type of organizational culture and the level of the management of employees at different ages.

Design/methodology/approach: The method of case study was applied. It has been hypothesized that the best level of managing age in an organization is guaranteed by the clan culture, which assumes cooperation, friendly work atmosphere and partnership, which is part of the assumptions of multigenerational management.

Findings: It should be emphasized at this point that the type of organizational culture adopted from above is not always the one that employees of the organization display in their everyday, direct contacts. The level of age management is low in the hierarchy-like type of organizational culture. This does not mean that there cannot be single elements of age management in it.

Research limitations/implications: Only one company was studied. In order to generalize research results, it is necessary to conduct research in more organizations. The research was part of the work carried out for the doctoral dissertation entitled "Conditions for managing employees of various age groups in an economic organization".

Practical implications: The main recommendation is the introduction of a cafeteria system, in which benefits for individual generations would be available.

Originality/value: The article presents the results of research aimed at identifying the dependence between the type of organizational culture and the level of management of employees at different ages.

Keywords: age management, mutigenerational management, generations, organizational culture.

Category of the paper: Empirical research.

\section{Introduction}

An unquestionable challenge for contemporary enterprises is coping with the challenges posed by demographic changes, including the phenomenon of an aging population and, consequently, a change in the structure of the whole society (increase in the share in the 
population of post-working age population and decrease in the proportion of people in pre-working age) and decline in manpower.

The situation on the labour market is unique today. There are four generations on it. Due to the fast pace of changes taking place in the world, people who differ in age by a few years can live in a completely different socio-economic situation. One of the solutions to this situation are effective actions in the area of "age" management (or more precisely, management of employees of different ages).

It should be noted, however, that the level of advancement of managing employees of different age groups in an organization depends on many different conditions. Among them are the size of the organization, the industry in which it operates, the legal regulations to which it is subject, its external environment, financial results, strategy, mission and vision of the organization, as well as culture - both organizational and national (the country from which the organization originates, in which it operates), as well as the resulting style of management, values or promoted attitudes. The relationship between the type of organizational culture that determines a number of the aforementioned conditions and the level of age management in the enterprise seems to be particularly interesting.

It should be emphasized at this point that the type of organizational culture adopted from above is not always the one that employees of the organization display in their everyday, direct contacts.

\section{Typology of organizational cultures according to Cameron and Quinn}

According to Hofstede, organizational culture is a collective mind programming that distinguishes members of one organization from others (Hofstede, Hofstede, Minkov, 2011, p. 352). It includes the values, belief norms and patterns of behaviour that the individual has been aware of for years and that are shared by all members of the organization, or which the individual is unaware of until they are violated or cease to be useful in everyday life.

The theory was built based on the factor analysed in terms of organizational performance indicators. As part of it, K.S. Cameron and R.E. Quinn created a model of competitive values. Two organizational efficiency criteria are the dimensions of the organizational culture description. The first one refers to independence, dynamism, invariance, order and control. The second is about efficiency. Its criteria include focus on internal affairs, integration and unity, focus on the position in the environment, diversification and rivalry (Stańczyk, 2008, p. 43).

According to this theory, one can distinguish the culture of the clan, hierarchy, adhocracy and the market. The first one assumes that an organization can be compared to a family. Noticeable are the flexibility and freedom of action, as well as the focus on internal affairs, 
people and processes. The leader is referred to as mentor, counsellor and father. They want to integrate the team. A lot depends on their managerial skills, especially in team management. Teamwork and the pursuit of consensus are highly valued. The organization shows a commitment to tradition. The employer tries to satisfy all the employees' needs (Cameron, Quinn, 2015, pp. 49-50, 71-72; Schein, 2010, p. 168).

Organizations where hierarchy culture takes place are usually well structured and wellcoordinated. Stability and continuous control as well as focus on internal affairs are visible at every stage of management. A valued leader can be described as a coordinator, observer and organizer. Their managerial skills play a key role, especially the management of assimilation, which involves making clear expectations and complying with standards. Subordination of procedures and compliance with regulations and rules make employees' behaviour easy to predict, which reduces the feeling of uncertainty (Cameron, Quinn, 2015, pp. 46-47).

Market culture is characterized by stability and control as well as orientation towards the position in the environment and diversity. The leader can be described as the supervisor, competitor and producer. It is particularly important to skilfully motivate employees and promote a customer-oriented attitude. It is important to effectively implement tasks and focus on the results and reputation of the organization. Employees are ambitious about their work, and successes are celebrated together (Cameron, Quinn, 2015, pp. 47-48).

The culture of adhocracy is characterized by flexibility and freedom of action as well as orientation towards the position in the environment and diversity. It is therefore oriented externally and flexible, innovative, dynamic and entrepreneurial. The leader is an innovator, entrepreneur and visionary. His skills include mainly innovation management, focus on the future and continuous improvement. The innovative products, creativity and growth are considered as efficiency criteria (Cameron, Quinn, 2015, pp. 51-53).

\section{Management of employees of different age groups in an enterprise}

One of the answers to the demographic processes currently taking place on the labour market, such as the aging of the workforce or the need to reconcile the needs of up to four generational groups of employees is properly structured age management system in the organization (or more strictly, management of employees of different ages). Age management can be defined as "a dynamic set of rules, methods, instruments, etc. regarding work and employment capacity, contributing to economic and social productivity throughout life (...)" (Woszczyk, Warwas, 2016, p. 39). This concept has relatively recently appeared in the science of management - in the world it has been described for over a dozen years, in Poland it appeared only in the last decade (Liwiński, Sztanderska, 2014). Certainly, this is not an obvious element of human resource management in Polish organizations. 
Age management often defines activities addressed only to the oldest employees and aimed at their activation. This is of course an important issue, but age management should rather be treated as a system aimed at reconciling the needs of employees of all generations working in the organization, assuming the exchange of knowledge and experiences between them and adapting all existing personnel systems in the company to the expectations of employees at different stages of life. The age management so constructed can be called multigenerational management (Woszczyk, Warwas 2016, p. 44). It seems that it is the most effective in the process of motivating employees and increasing the efficiency of their work. Thus, it can lead to an increase in the company's financial results.

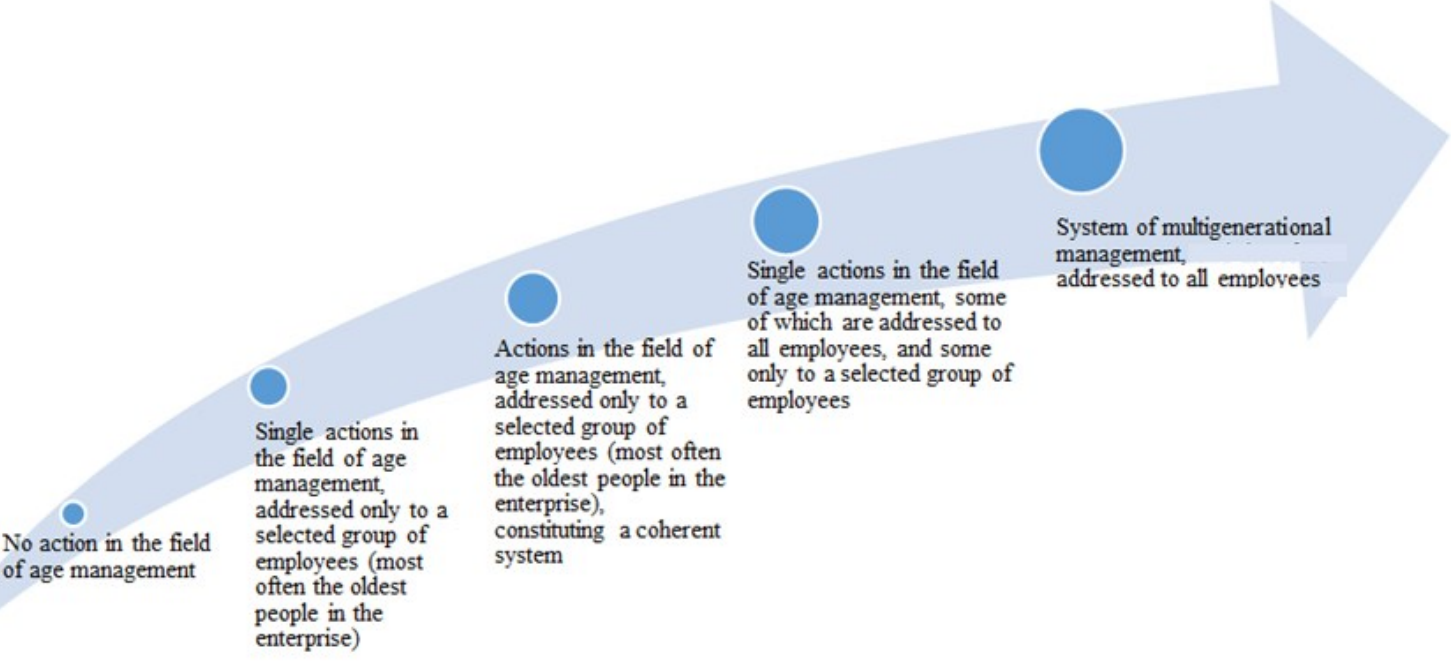

Figure 1. Levels of age management in the organization. Source: own elaboration.

It is worth adding that the level of advancement of managing employees of different age in the organization depends on many different conditions. Among them are the size of the organization, the industry in which it operates, the legal regulations to which it is subject, its external environment, financial results, strategy, mission and vision of the organization, as well as culture - both organizational and national (the country from which the organization originates and country in which it operates), as well as the resulting style of management, values or promoted attitudes.

\section{Methods}

In the conducted research an attempt was made to recognize the dependence between the type of organizational culture (according to the Cameron and Quinn typology) - both this adopted by the organization from the top, as well as this manifested by employees in less formal situations - and activities in the field of age management in the enterprise. This is the main purpose of this article. 
The case study method was applied. The described organization is Aquanet, a water and sewage company based in Poznań.

The tests carried out consisted of several stages. They started with pilot studies, in which a human resources department member filled out two questionnaires. The first one was a part of the Cameron and Quinn Questionnaire regarding the current type of organizational culture (the part concerning the desired type was omitted, as this was not the subject of the research). The second questionnaire focused on activities in the management of employees of different ages in the organization. Next, basic research was carried out, the aim of which was to confirm the type of organizational culture and to further recognize the level of age management. It consisted of interviews conducted with managers, a survey addressed to employees, document analysis, as well as observation of the work of the multigenerational team. The research was part of the work carried out for the doctoral dissertation entitled "Conditions for managing employees of various age groups in an economic organization". Aquanet is the first company that participated in the research.

It has been hypothesized that the best way of age management in an organization is guaranteed by the clan culture, which assumes teamwork, cooperation, friendly work atmosphere and partnership, which is part of the assumptions of intergenerational management. In the hierarchy culture, age management will be limited only to activities directed to the oldest employees and will not be developed. In the culture of adhocracy, age management will not exist, because in this type of organizational culture, it is difficult to find any personnel systems. In turn, a market-oriented organization, focused on profit and satisfying the client's needs, will try to motivate employees to the most efficient work, however, simultaneous competition and excessive concern about the final result will not allow for the development of an effective age management system.

\section{Results}

In the course of the conducted research, it was established that Aquanet has an organizational culture of the hierarchy type. This is shown both by the results of surveys and interviews carried out, as well as by the analysis of documents. Only the observation showed that in everyday, direct employee contacts there are manifestations of a clan culture.

There is no separate age management system in the organization under study (let alone multigenerational management). However, there are single elements that belong to other personnel systems, which can be considered as components of the management of age-diverse employees in the enterprise. 
There are activities in Aquanet that can be considered as mentoring. In many departments, a new employee receives a supervisor, an experienced person who has been working in the organization for many years, who introduces them to the tasks of a given position. Such person receives in exchange for additional duties an appropriate reward, the amount of which, however, depends on the recognition of the immediate superior. It should be emphasized here that there is no formal mentoring system in the organization. Assigning a guardian is an individual decision of the manager of the team.

Also part of the activities in the area of corporate social responsibility can be classified as age management. It is worth noting that Aquanet has assumed patronage over the class in which students learn to become a fitter of the installation network and sanitary equipment in the Zespól Szkół Budowlanych in Poznań, which goal is to participate in the education of the future staff. However, other activities in the field of age management in the area of employee recruitment are unnoticeable.

Extensive activities in the field of health protection are also significant, such as co-financing of private medical care, blood donation campaigns, mammography for women, examination of birthmarks and organization of so-called days of health. It is worth emphasizing that older employees belonging to the baby boomers generation can count on a wider package of medical tests and more frequent periodic tests than it is required by law.

For employees in the pre-retirement age, information meetings in cooperation with the Social Insurance Institution (Zakład Ubezpieczeń Społecznych) have been organized as well. It should be highlighted that, although it is not a top-down practice, some managers commission less tiring tasks to employees of the baby boomers generation, without changing their position. This is especially important for manual workers, whose health does not allow them to continue to perform their on-going duties.

Employees in office positions also have the opportunity to take advantage of flexible working time (arriving at work is allowed from 7:00 to 10:00) and to work remotely for one day every two weeks, which certainly facilitates the reconciliation of work and personal life, which is especially important for younger generations.

Aquanet promotes also lifelong learning by organizing English language lessons during work and co-financing post-graduate studies, provided that their subject is consistent with the needs of the company.

In the organization employment plans are also created every year (containing mainly plans for potential retirement and the need for new employees). Unfortunately, they are not related to employee succession plans, although both managers and regular employees believe that it is indispensable. It is worth emphasizing that some managers of multigenerational teams, within the framework of the informal monitoring mentioned above, choose pairs of employees who are to retire in the coming years and the youngest, recently employed ones. Thanks to this, employees can exchange knowledge and experience. 
The organization also supports intergenerational cooperation through the organization of a company picnic, which allows the integration of employees of different ages, and the organization of trainings of young employees, which are conducted by experienced employees. It is worth noting that employees take part in a training to prevent discrimination based on age, however, employees note that Aquanet is not taking any actions that could prevent intergenerational conflicts.

The surveyed managers emphasize that it would be a great idea to introduce benefit groups targeted at specific groups of recipients of different ages, e.g. funding a nursery and kindergarten for children of employees of generations $\mathrm{Z}$ and $\mathrm{Y}$, expert training for employees of the $\mathrm{X}$ generation, as well as broader activities targeted at employees of the baby boomers generation. In their opinion, it would be necessary to restore the apprenticeship allowance, which was abolished several years ago.

\section{Discussion}

It was clearly stated that there are single elements of age management in the organization under study. Moreover, they are directed primarily to the oldest group of employees. According to the theory proposed in the article, Aquanet is on the second level of age-diverse employees management.

It is worth noting that some of these activities are not formalized or imposed. Their use depends only on the awareness, knowledge and management skills of a given team leader.

This confirmed the hypothesis that hierarchical culture is not friendly towards managing age in an organization, let alone managing intergenerational staff. It should also be emphasized that where age management activities take place (that is, they are related to manifestations of the clan culture that manifests itself in Aquanet in everyday work and contacts, both between employees and their superiors), they result mainly from grassroots initiatives of individual managers of departments. It is worth emphasizing, however, that these are individual elements, which do not constitute a coherent system of managing employees of various age groups. Thus, it can be stated with all certainty that the main type of culture determines the level of age management in the enterprise under study in an important way.

Respondents, however, clearly expressed the need to introduce formalized forms of managing employees of different ages. They noticed in particular the necessity to create plans of employee succession and adaptation of the incentive system in force to the needs of various age groups of recipients. However, in order to prevent accusations of favouring some employees (which is a thread for the employees of the personnel department), a good solution could be the introduction of a cafeteria system in which benefits for individual generations would be available, however they would be available to all employees. This is the main 
recommendation for the organization under study, where hierarchy and clan cultures exist together.

\section{Summary}

In summary, in a hierarchy-like culture, a coherent system of age management (and even more so of multigenerational management) is rare. This does not mean, however, that there cannot be single elements of age management in it, but they are often provided by managers of multigenerational teams and are not formalized. However, they should be addressed to all employees, regardless of their age. It is important to respond to the needs of all employees, which may increase their effectiveness.

It should be noted that it is the imposed type of organizational culture that determines the level of age management in the enterprise, and not the culture type manifested in everyday, direct employee contacts. Thus, the previously stated hypothesis was confirmed.

\section{References}

1. Cameron, K.S., Quinn, R.E. (2015). Kultura organizacyjna - diagnoza i zmiana. Model wartości konkurencyjnych. Warszawa: Wolters Kluwer.

2. Hofstede, G., Hofstede, G.J., Minkov, M. (2011). Kultury i organizacje. Zaprogramowanie umystu. Warszawa: PWE.

3. Liwiński, J., Sztanderska, U. (2013). Standardy zarządzania wiekiem w organizacjach. Warszawa: PARP.

4. Schein, E.H. (2010). Organizational culture and leadership. San Francisco: Joessey-Bass A Wiley Imprint.

5. Stańczyk, S. (2008). Nurt kulturowy w zarządzaniu. Wrocław: Wydawnictwo Uniwersytetu Ekonomicznego.

6. Woszczyk, P., Warwas, I. (2016). Od zarządzania wiekiem do zarządzania międzypokoleniowego. In: J. Wiktorowicz, I. Warwas, M. Kuba, E. Staszewska, P. Woszczyk, A. Stankiewicz, J. Kliombka-Jarzyna, Pokolenia - co się zmienia? Kompendium zarzadzania multigeneracyjnego (pp. 38-55). Warszawa: Wolters Kluwer. 